\title{
Effect of Biscuit Enriched with Bilih Fish (Mystacoleucus padangensis) on Growth of Experimental Rats
}

\author{
Fivi Melva Diana ${ }^{1 *}$, Rimbawan $^{2}$, Evy Damayanthi², Mira Dewi $^{2}$, \\ Vetnizah Juniantito ${ }^{3}$, Nur Indrawaty Lipoeto ${ }^{4}$ \\ ${ }^{1}$ Faculty of Public Health, Andalas University, Padang 25137, Indonesia \\ ${ }^{2}$ Department of Community Nutrition, Faculty of Human Ecology, IPB University, Bogor 16680, Indonesia \\ ${ }^{3}$ Faculty of Veterinary Medicine, IPB University, Bogor 16680, Indonesia \\ ${ }^{4}$ Medical Faculty, Andalas University, Padang 25128, Indonesia
}

\begin{abstract}
The research aimed to produce biscuits formulated with Bilih fish and to analyse the effect of Bilihfish-based biscuits on the growth of experimental rats. Six biscuit formulas were developed using three different amounts of Bilih fish flour $(0 \mathrm{~g}, 20 \mathrm{~g}$, and $30 \mathrm{~g}$ added to one formula dough) and two flavors (chocolate and vanilla). One biscuit formula was selected based on the best organoleptic test. Four treatments were applied to 24 male growing rats (21 day olds of the Spraque Dawley strain) for 28 days using a completely randomized design study. The treatments used were P1 (standard feed), P2 (standard feed + standard biscuits), P3 (standard feed + standard biscuits + pure omega-3 oil) and P4 (standard feed + the best formula biscuit). The parameters measured on rats were weight and tail length. The best formula biscuit based on the organoleptic test was the chocolate-flavor biscuits prepared with $20 \mathrm{~g}$ Bilih fish flour. The longest tail length was found in the P4 treatment $(2,257 \pm 0.52 \mathrm{~cm})$, which was significantly longer than the $\mathrm{P} 2(1.46 \pm 0.34 \mathrm{~cm})$ and $\mathrm{P} 1(1.34 \pm 0.29 \mathrm{~cm})$ treatments. No significant weight differences were found among the rats in all treatments. Hence, the chocolate-flavor biscuits formulated with the addition of $20 \mathrm{~g}$ Bilih fish flour increased the linear growth in experimental rats as shown by the significant difference in the tail lengths found in the treatment group.
\end{abstract}

Keywords: bilih fish flour, biscuit formulation, omega-3, tail length, weight

\section{INTRODUCTION}

The first 1,000 days of life is a golden period for child development. It starts with 270 days during pregnancy, followed by 730 days or two years after birth (BAPPENAS 2015). Omega-3 fatty acids play an important role in the growth and development within the first 1,000 days. A previous study has reported that the lack of omega-3 fatty acids consumption may cause stunting in humans (Diana 2013).

Many studies on experimental animals also show that omega-3-fatty-acid-deficient diet is associated with faltered growth. One of the omega-3 fatty acid components that plays an active role in growth is the DHA (docosahexaenoic acid). In addition, other studies have also mentioned that omega-3 fatty acids in the diet play an important role in fetal growth. However, the clinical mechanisms on how the omega- 3 fatty acids affect growth still needs further research (Bernardi 2012).
Omega-3 fatty acids and proteins are widely present in various types of fish, and the increased consumption of local fish will improve the nutritional status in children and the local economy. However, fish has certain organoleptic properties which are not necessarily favored by children. Thus, there is a need to develop fish-based products that are able to improve acceptance among children as consumers.

Widodo (2015) had demonstrated the use of locally processed food products with freshwater fish in the form of biscuits, namely the snakehead-murrel-based biscuits that can improve the nutritional status of under-fiveyear-old children. Biscuits were chosen because they can be consumed by all ages and socioeconomic strata, are easy to store, have a long shelf life and are easy to produce and distribute. Furthermore, they can also be adjusted to the child's digestion and be shaped in such a way as to increase the children's acceptance.

\footnotetext{
"Corresponding Author: tel: +6285263610820, email: fividiana0503@gmail.com
} 
Bilih fish (Mystacoleucus padangensis) is a local fish from Solok, West Sumatera. It contains nutrients such as proteins, fats, vitamins, and minerals (Syandri 2008). The results of the preliminary study in this research show that Bilih fish contains a high level of omega-3 fatty acids $(0.553 \mathrm{~g} / 100 \mathrm{~g}$ of fresh fish). Thus, it is important to study the potential Bilih fish has as an ingredient for nutritious biscuits development to improve children growth. The study should start with an animal study before further steps in human subject are taken. The study offers scientific evidence on the development process and effect of biscuits enriched with Bilih fish that is rich in omega-3 fatty acids in an animal study, which serves a basis for a further human study.

\section{METHODS}

\section{Design, location, and time}

The experimental design used was the Completely Randomized Design (CRD). The biscuit development was conducted in the Laboratory of the Department of Community Nutrition, IPB University, whereas macro- and micronutrient analyses were conducted at the GIS Laboratory (Saraswanti Indo Genetech), Bogor, West Java. Meanwhile, the growth assessment of the research animal was conducted at the Animal Veterinary Hospital (RSHP), Faculty of Veterinary Medicine, IPB University. This research was conducted from March 2016 until January 2018. The study had obtained an ethical clearance number 72-2017 from the Animal Ethics Committee of the Institute of Research and Community Service, IPB.

\section{Materials and tools}

The material used in this research was Bilih fish that was made into flour and then formulated into biscuits. The biscuits were made from wheat flour, egg, fine sugar, margarine, full cream milk, vanilla powder, and chocolate powder. The fish flour was made with dump dryer, oven, blender, grinding machine, spoon, spatula, knife, basin, pan, wok, blender, mixer, biscuit mold, flour sieve, and stove. The animal subjects were white rats aged 21 days of the Sprague Dawley strain.

\section{Procedure}

The research was divided into two phases. The first phase was the development of the Bilih
Fish-based biscuits, and the second phase was the study of the effect of biscuit intervention on the rats' growth.

Bilih fish-based biscuit development. The Bilih fish used were around 4.0-8.5 cm in length and $0.5-5.1 \mathrm{~g}$ in weight. The fish was caught at 100-300 yards depth of Singkarak Lake at relatively low water temperatures between 24.0 $26.0^{\circ} \mathrm{C}$.

Fish flour preparation. The process of making the fish flour began by cleaning the fish then drying it under the sun for approximately 11 hours/day from 7 am until 6 pm over 7 days, making up a total of 77 hours, until the moisture content reached $\pm 4 \%$. The dried fish was then smoothed in a drum dryer at a temperature of $80^{\circ} \mathrm{C}$ for approximately 15 minutes for $1 \mathrm{~kg}$ of fresh Bilih fish, then mashed and sieved with a 60 -mesh sieve. The fish flour obtained from 1 $\mathrm{kg}$ of fresh fish was around 290-320 g, or in the ratio of about 1:3, with light brown color and a smooth texture. The fish flour was then analysed for nutrient content before being used as an ingredient in biscuits.

Formulation of the biscuit product made from Bilih fish. The aim of this phase was to develop the biscuit using six biscuit formulas. Table 1 shows the dough formulation of Bilih fish biscuits, then the biscuits were molded and baked for 35 minutes at temperatures of $160-165^{\circ} \mathrm{C}$, and then cooled.

The amount of full cream milk used in the chocolate-flavored biscuit formula was lower than that used in the vanilla-flavored biscuit formula because some of the weight of the full cream milk was replaced by chocolate powder to result in the same weight of dry inggridients. The organoleptic test used was the hedonic test that involved 40 respondents. Respondents assessed the color, flavor, taste, texture, and overall quality of the six biscuit product formulas (Table 1). The selection of the best biscuit formula was done based on the respondents' hedonic test, in which the biscuits were assessed and assigned a score of 1 to 7 , detailed as follows: score 1 was interpreted as extreme dislike, 2 as moderate dislike, 3 as slight dislike, 5 as slight like, 6 as moderate like, and 7 as extreme like. For the assessment of hedonic quality test, the best formula was assessed based on the color from score 1=dark chocolate to score $7=$ golden yellow, based on the texture from score $1=$ very hard to score 
Table 1. Formulation of fish-based biscuit product

\begin{tabular}{lcccccc}
\hline \multirow{2}{*}{ Ingredients } & \multicolumn{3}{c}{ Chocolate } & \multicolumn{3}{c}{ Vanilla } \\
\cline { 2 - 7 } & F0 & F20 & F30 & F0 & F20 & F30 \\
\hline Fish flour (g) & - & 20 & 30 & - & 20 & 30 \\
Wheat flour (g) & 225 & 225 & 225 & 225 & 225 & 225 \\
Egg yolk (unit) & 1 & 1 & 1 & 1 & 1 & 1 \\
Fine sugar (g & 150 & 150 & 150 & 150 & 150 & 150 \\
Margarine (g) & 300 & 300 & 300 & 300 & 300 & 300 \\
Full cream milk (g) & 30 & 30 & 30 & 80 & 80 & 80 \\
Vanilla powder (tsp) & 0.5 & 0.5 & 0.5 & 0.5 & 0.5 & 0.5 \\
Chocolate powder (g) & 50 & 50 & 50 & - & - & - \\
Liquid vanilla (tbsp) & - & - & - & 2 & 2 & 2 \\
\hline
\end{tabular}

$7=$ very crunchy, based on the aroma from score $1=$ very hard to score $7=$ very weak, and based on other properties from score $1=$ very weak to score $7=$ very strong (Setyaningsih et al. 2010). The best formula obtained from the organoleptic test was then analysed for the nutrient content. The decision making on the selection of the best formula was based on the attributes that gave the highest value after standard biscuit.

Nutrient analysis. The proximate nutrient analysis and fatty acid analysis of the fresh Bilih fish, Bilih fish flour, the biscuit with the best organoleptic properties, and the standard biscuit were performed using AOAC methods (AOAC 2005). The analyses included the protein content (Kjeldahl method), fat content (Soxhlet method), ash content (Gravimetric method), moisture content (oven method), carbohydrate content (by difference method), and total energy (by calculation).

The fatty acid content, especially the omega-3 fatty acids, in fresh Bilih fish, Bilih fish flour, the selected biscuit, and standar biscuit was analysed using the Gas Chromatography method. The procedure stages for the analyses were as follows: 1. standard solution preparation; 2. sample preparation (including a. fat content determination, $b$. fat extraction by cold extraction, c. methylation of fat); and 3. omega-3 fatty acids analysis with GC FID (Gas CromatographyFlame Ionization Detector) (AOAC 2001). The chromatography conditions were as follows: column=Supelco SPTM $2560100 \mathrm{~m} 0.25 \mathrm{~mm} 0.2$ um; water rate $=18.0 \mathrm{~cm} / \mathrm{sec}$ with column length $100 \mathrm{~m}$; carrier gas $=\mathrm{N}_{2}$; detector $\mathrm{FID}=240^{\circ} \mathrm{C}$; injector temperature $=225^{\circ} \mathrm{C}$; Split $=1: 100 \quad$ (Khan et al. 2017).

The effects of biscuit intervention on the growth of Sprague dawley rats. The aim of this phase was to study the effect of administration of selected Bilih fish biscuit formula on the growth of the experimental rats. The rats were placed in pairs in a cage and in a room with a light and dark period of 12 hours each. The cage temperature ranged from $23.9^{\circ} \mathrm{C}$ to $26.6^{\circ} \mathrm{C}$ with an average temperature of $25.5^{\circ} \mathrm{C}$, and the air humidity ranged from $67 \%$ to $88 \%$ with an average humidity of $81 \%$.

The rats were given standard daily rations (including water) ad libitum for 14 days of acclimatization period. All rats then entered the treatment period of 28 days. The rats were divided into four groups and were given $20 \mathrm{~g}$ /day of standard feed orally. In addition to that, during the treatment period each group of rats was also given one treatment feed by gastric tube feeding method. These included P1 (0.2 g standard feed + $6 \mathrm{ml}$ aqua bidest per day), P2 (2.43 $\mathrm{g}$ of standard biscuit $+6 \mathrm{ml}$ aqua bidest per day), P3 (2.43 g of standard biscuits $+0.014 \mathrm{~g}$ of pure omega- 3 oil + $6 \mathrm{ml}$ aqua bidest per day), and P4 (2.09 $\mathrm{g}$ of the selected formula of Bilih fish biscuits $+6 \mathrm{ml}$ aqua bidest per day). The doses of pure omega- 3 oil and omega- 3 in the biscuits were calculated based on the National Recommended Daily Allowance for omega-3 (0.7 g/day) for children aged 1-3 
years (Kemenkes 2013). Based on the Food and Drugs Administration (FDA 2005) guideline, the doses were then converted to rat doses, which were equivalent to $2.43 \mathrm{~g}$ /day of standard biscuit, $0.014 \mathrm{~g} /$ day of pure omega-3 oil, and $2.09 \mathrm{~g} /$ day of selected Bilih fish biscuit respectively.

During the treatment period, the rat weight and tail length were measured once every 7 days. The weight was measured using a digital weighing instrument with $0.1 \mathrm{~g}$ accuracy. Then, the tail length was measured using a caliper with $1 \mathrm{~mm}$ accuracy. The tail length was measured from the position of anus to the tip of the tail, the hair at the end of the tail excluded (Sholichah 2007).

\section{Data analysis}

Descriptive analysis was applied for the organoleptic test scores, including the average, variance, and standard deviation of any combination of the Bilih fish-based biscuits. The hedonic test scores were analysed using the Kruskal Wallis test and the post hoc Dunn test. Data on the body weights and tail lengths of the rats were analysed using the ANOVA and the post hoc Tukey test at a 95\% confidence level $(\alpha=0.05)$ (Mattjik \& Sumertajaya 2013).

\section{RESULTS AND DISCUSSION}

\section{Research phase one: Bilih fish-based biscuit development}

Bilih fish (Mystacoleucus padangensis) is a lake-dwelling fish that migrates upstream to spawn. The main diet of this fish is detritus and zooplankton. It also feeds on phytoplanktons and other vegetable materials that fall into the water (Kartamihardja \& Sarnita 2010). Mystacoleucus padangensis fishes spawn in the stream that empties into rivers around Singkarak River like Batang Sumpur River, Paninggahan River, and Muaro Pingai River. The females release eggs at the bottom of the river, which are fertilized by the males and sink to the bottom, then drift into the lake (Kartamihardja 2015). Bilih fish is a source of proteins, fats, vitamins, and minerals (Yuniritha et al. 2014).

Fresh Bilih fish contains $0.553 \mathrm{~g}$ omega-3 fatty acids in $100 \mathrm{~g}$, while the dry Bilih fish flour contains $1.691 \mathrm{~g}$ omega-3 fatty acids in $100 \mathrm{~g}$ (Table 2). According to LIPI (1999), the chemical composition of fish flour is determined by the type of the fish.
Table 2. Omega-3 fatty acid content of Bilih fish fresh and Bilih fish flour obtained from Singkarak Lake 2016

\begin{tabular}{lcc}
\hline \multicolumn{1}{c}{ Parameters } & $\begin{array}{c}\text { Bilih fresh } \\
\text { fish }\end{array}$ & $\begin{array}{c}\text { Dry fish } \\
\text { flour }\end{array}$ \\
\hline Omega-3 fatty acid (g) & 0.553 & 1.691 \\
Alpha linolenic acid (g) & $\begin{array}{c}\text { Not } \\
\text { analysed }\end{array}$ & 0.423 \\
DHA (g) & 0.237 & 0.572 \\
EPA (g) & 0.207 & 0.732 \\
Omega-6 fatty acid (g) & 0.252 & 1.146 \\
Linolenic acid (g) & $\begin{array}{c}\text { Not } \\
\text { analysed }\end{array}$ & 0.600 \\
AA (g) & 0.096 & 0.408 \\
Moisture (\%) & 76.44 & $\begin{array}{c}\text { Not } \\
\text { analysed }\end{array}$ \\
\hline
\end{tabular}

Table 3 shows the hedonic test results of the average score of each Bilih fish biscuit formula based on the characteristics such as color, aroma, taste, texture, and overall attribute. The most preferred formula was the F20 formula which featured the administration of $20 \mathrm{~g}$ Bilih fish flour to one formula dough with chocolate flavor. The hedonic test scores by the respondents for the F20 formula were 4.88 for color, 4.11 for flavor, 4.21 for taste, 5.46 for texture, and 4.70 for the overall acceptance. This formula was then selected as the Bilih fish biscuit administered to the experimental rats.

The omega-3 fatty acid content in the F20 biscuit (20 g Bilih fish flour added to one formula dough with chocolate flavor) was $0.669 \mathrm{~g} / 100 \mathrm{~g}$ biscuit while the F0 biscuit or the standard biscuit contained only $0.575 \mathrm{~g} / 100 \mathrm{~g}$ biscuit of omega-3 fatty acid. The F20 biscuit also contained DHA $(0.010 \mathrm{~g} / 100 \mathrm{~g}$ biscuit) and EPA $(0.012 \mathrm{~g} / 100 \mathrm{~g}$ biscuit), which were not found in the F0 biscuit. The ratio of omega- 3 to omega- 6 fatty acids in the F20 biscuit was 1:5 (Table 4).

The Indonesian RDA of omega-3 fatty acid for children aged $1-3$ years is $0.7 \mathrm{~g}$ (Kemenkes 2013). The data in Table 4 show that $0.7 \mathrm{~g}$ of omega-3 fatty acids can be obtained from around $100 \mathrm{~g}$ of F20 biscuit as it contains $0.669 \mathrm{~g}$ of omega-3 fatty acids.

Table 5 presents the chemical composition of the F0 and F20 biscuits as compared to the 
Table 3. Results of hedonic test of biscuits

\begin{tabular}{cccccc}
\hline \multirow{2}{*}{ Formula } & \multicolumn{5}{c}{ Attributes } \\
\cline { 2 - 6 } Chocolate & Color & Flavor & Taste & Texture & Overall \\
F0 & & & & & \\
F20 & $6.08^{\mathrm{c}}$ & $5.44^{\mathrm{c}}$ & $5.78^{\mathrm{b}}$ & $5.14^{\mathrm{ab}}$ & $5.58^{\mathrm{b}}$ \\
F30 & $4.88^{\mathrm{a}}$ & $4.11^{\mathrm{ab}}$ & $4.21^{\mathrm{a}}$ & $5.46^{\mathrm{a}}$ & $4.70^{\mathrm{a}}$ \\
Vanilla & $5.56^{\mathrm{b}}$ & $3.94^{\mathrm{ab}}$ & $3.65^{\mathrm{a}}$ & $5.29^{\mathrm{b}}$ & $4.58^{\mathrm{a}}$ \\
F0 & & & & & \\
F20 & $5.73^{\mathrm{bc}}$ & $5.60^{\mathrm{c}}$ & $5.84^{\mathrm{b}}$ & $5.78^{\mathrm{c}}$ & $5.75^{\mathrm{b}}$ \\
F30 & $5.45^{\mathrm{b}}$ & $4.35^{\mathrm{b}}$ & $4.15^{\mathrm{a}}$ & $4.76^{\mathrm{a}}$ & $4.63^{\mathrm{a}}$ \\
p value & $4.70^{\mathrm{a}}$ & $3.71^{\mathrm{a}}$ & $3.86^{\mathrm{a}}$ & $4.99^{\mathrm{a}}$ & $4.34^{\mathrm{a}}$ \\
\hline
\end{tabular}

Different letters in the same column show significant differences $(\mathrm{p}<0.05)$ with Kruskal Wallis test; Colour: $1=$ dark chocolate to $7=$ golden yellow; Texture: $1=$ very hard to $7=$ =ery crunchy; Aroma: $1=$ very hard to $7=$ =very weak; Others: $1=$ very weak to $7=$ very strong

Indonesia Recommended Daily Allowance (RDA) for children aged 1-3 years of energy, proteins, fats, carbohydrates, omega-3, omega-6, moisture, and fiber. The F20 biscuits in this study can be considered a good source of energy and omega-3 fatty acids.

\section{Research phase two: The study of the effect of biscuit intervention on the growth of Sprague dawley rats \\ Table 6 shows the mean and standard} deviation of rat body weights for P1, P2, P3 and $\mathrm{P} 4$ at six different measurement times. The

Table 4. Analysis of fatty acids in $100 \mathrm{~g} \mathrm{~F} 0$ and F20 chocolate biscuits

\begin{tabular}{lcc}
\hline \multicolumn{1}{c}{ Parameters $(\mathrm{g})$} & $\begin{array}{c}\text { F0 } \\
\text { Chocolate }\end{array}$ & $\begin{array}{c}\text { F20 } \\
\text { Chocolate }\end{array}$ \\
\hline Omega-3 fatty acid & 0.575 & 0.669 \\
Alpha linolenic acid & 0.574 & 0.663 \\
DHA & ND & 0.010 \\
EPA & ND & 0.012 \\
Omega-6 fatty acid & 3,261 & 3,489 \\
Linolenic acid & 3,246 & 3,456 \\
AA & 0.005 & 0.013 \\
\hline
\end{tabular}

ND: Not detected; F0: Standard biscuit with chocolate flavor; F20: Biscuit formulated by adding $20 \mathrm{~g}$ Bilih fish flour to one formula dough with chocolate flavor
ANOVA results show there was no significant difference in the body weights of the rats, although the average difference in weight gain of the rats in $\mathrm{P} 4(61.57 \pm 9.10 \mathrm{~g})$ was higher than those in P3 $(53.60 \pm 20.45 \mathrm{~g}), \mathrm{P} 2(51.60 \pm 14.55 \mathrm{~g})$ and P1 (45.20 $\pm 18.21 \mathrm{~g})$, respectively. The results were in line with those reported by Firmansyah et al. (2017), who state that the intervention of catfish oil fortified by omega-3 fatty acids and vitamin $\mathrm{E}$ increased the body weight in rats, but not significantly.

Table 7 shows the mean and standard deviation of the tail lengths of the rats for P1,

Table 5. Chemical composition of biscuits as compared to RDA*

\begin{tabular}{|c|c|c|c|}
\hline $\begin{array}{l}\text { Chemical } \\
\text { composition of } \\
\text { biscuit }(/ 100 \mathrm{~g})\end{array}$ & $\begin{array}{c}\text { F0 } \\
\text { chocolate }\end{array}$ & $\begin{array}{c}\text { F20 } \\
\text { chocolate }\end{array}$ & $\begin{array}{l}\text { The } \\
\text { Indonesia } \\
\left(\mathrm{RDA}^{*}\right)\end{array}$ \\
\hline Energy (kcal) & 528.16 & 518.09 & 1,125 \\
\hline Protein $(\mathrm{g})$ & 5.34 & 6.66 & 26 \\
\hline Total fats (g) & 29.25 & 27.81 & 44 \\
\hline Carbohydrate (g) & 60.28 & 60.29 & 155 \\
\hline Omega-3 (g) & 0.58 & 0.69 & 0.7 \\
\hline Omega-6 (g) & 3.26 & 3.49 & 7.0 \\
\hline Moisture (g) & 2.92 & 3.00 & - \\
\hline Fibre (g) & 7.32 & 6.40 & 16 \\
\hline \multicolumn{4}{|c|}{$\begin{array}{l}\text { F0: Standard biscuit with chocolate flavor; F20: Biscui } \\
\text { formulated by adding } 20 \mathrm{~g} \text { Bilih fish flour to one formula } \\
\text { dough with chocolate flavor; RDA*: Recommended daily } \\
\text { allowance, for children aged } 1-3 \text { years }\end{array}$} \\
\hline
\end{tabular}


Diana et al.

Table 6. Measurement of the weight of the rats pre- and post-treatment

\begin{tabular}{ccccc}
\hline \multirow{2}{*}{ Treatment } & \multicolumn{4}{c}{ Measurement of weight $(\mathrm{g})$} \\
\cline { 2 - 5 } & Pre & Post & $\Delta$ & $\mathrm{p}^{*}$ \\
\hline P1 & $109.80 \pm 13.55$ & $155.00 \pm 20.50$ & $45.20 \pm 18.21$ & - \\
P2 & $93.40 \pm 17.70$ & $145.00 \pm 28.90$ & $51.60 \pm 14.55$ & 0.35 \\
P3 & $93.00 \pm 11.70$ & $146.60 \pm 26.10$ & $53.60 \pm 20.45$ & - \\
P4 & $100.00 \pm 14.50$ & $161.60 \pm 19.30$ & $61.57 \pm 9.10$ & - \\
\hline
\end{tabular}

"not significant with $\mathrm{p}>0.05$ (ANOVA test); $\mathrm{P} 1=$ standard feed; $\mathrm{P} 2=$ standard feed + standard biscuit; $\mathrm{P} 3=$ standard feed + standard biscuit + pure omega-3 oil and P4=standard feed + selected Bilih fish biscuit (administration of $20 \mathrm{~g}$ Bilih fish flour to one formula dough with chocolate flavor

$\mathrm{P} 2, \mathrm{P} 3$, and $\mathrm{P} 4$ in six measurements. The tail lengths, at both the start and end times, have a greater length difference in $\mathrm{P} 4(2.257 \pm 0.52 \mathrm{~cm})$ compared to P3 $(1.64 \pm 0.34 \mathrm{~cm}), \mathrm{P} 2(1.46 \pm 0.34$ $\mathrm{cm})$, and $\mathrm{P} 1(1.34 \pm 0.29 \mathrm{~cm})$, respectively. The ANOVA test results show that there was a more significant difference in the tail length growth in P4 treatment compared to other treatments. The Tukey test results show that P4 $(2.257 \pm 0.52 \mathrm{~cm})$ was more significantly different compared to P3 $(1.64 \pm 0.34 \mathrm{~cm}), \mathrm{P} 2(1.46 \pm 0.34 \mathrm{~cm})$, and P1 $(1.34 \pm 0.29 \mathrm{~cm})$.

The increase in weight gain tendency (although it was not significant) and significant improvement in tail length were resulted from the administration of $20 \mathrm{~g}$ Bilih fish flour in the chocolate flavor biscuits or the F20. The F20 contains protein (6.66 g/100 g biscuit), omega-3 fatty acid $(0.669 \mathrm{~g} / 100 \mathrm{~g}$ biscuit), alpha-linolenic acid (0.663 g/100 g biscuit), DHA (0.01 g/100 g biscuit), and EPA (0.01 g/100 g biscuit). Omega-3 fatty acid and protein are nutrients that play a role in mammalian growth.
Both of the animal and human studies also show the same results where Watkins et al. (2003) and Wargo et al. (2005) state that the addition of omega- 3 and omega- 6 contained in fish oil could increase the body weight. Several previous research studies also mentioned that a higher intake of omega-3 fatty acids, especially DHA and ALA, is associated with improvement of birth weight and birth length in developing countries (Bernardi 2012).

The development of myelin in the neuroendocrine cells needs adequate intake of omega-3 fatty acids (EPA, DHA). These neuroendocrine cells produce growth hormone such as somatotropin which plays a role in the growth of weight and tail length. An increase in the intake of omega-3 fatty acids leads to increasing endocrine cells and growth hormone (Stewart et al. 2009). Omega-3 fatty acids which then are converted into DHA also affect growth hormone such as IGF-1 (Singh 2005). As Simarmata et al. (2012) state, various pre-clinical and clinical studies have already demonstrated

Table 7. Measurements of tail length of rats pre- and post-treatment

\begin{tabular}{ccccc}
\hline \multirow{2}{*}{ Treatment } & \multicolumn{4}{c}{ Measurement of tail length $(\mathrm{cm})$} \\
\cline { 2 - 5 } & Pre & Post & $\Delta$ & $\mathrm{p}^{*}$ \\
\hline P1 & $12.74 \pm 2.30$ & $14.08 \pm 2.30$ & $1.34 \pm 0.29^{\mathrm{a}}$ & - \\
P2 & $13.22 \pm 0.60$ & $14.68 \pm 0.70$ & $1.46 \pm 0.34^{\mathrm{a}}$ & 0.007 \\
P3 & $12.78 \pm 0.96$ & $14.42 \pm 1.13$ & $1.64 \pm 0.34^{\mathrm{a}}$ & - \\
P4 & $12.98 \pm 0.70$ & $15.24 \pm 0.50$ & $2,257 \pm 0.52^{\mathrm{b}}$ & - \\
\hline
\end{tabular}

Different letters in the same column show *significant differences $\mathrm{p}<0.05$ (ANOVA test); $\mathrm{P} 1=$ standard feed; P2=standard feed + standard biscuit; $\mathrm{P} 3=$ standard feed + standard biscuit + pure omega- 3 oil and P4=standard feed + selected Bilih fish biscuit (administration of $20 \mathrm{~g}$ Bilih fish flour to one formula dough with chocolate flavor) 
the role of n-long-chain polyunsaturated fatty acids (LCPUFAs) in growth.

\section{CONCLUSION}

In conclusion, the biscuit made from 20 $\mathrm{g}$ Bilih fish flour added to one formula dough with chocolate flavor was found to be the best formula to achieve the nutrition density intended and the most preferred in terms of organoleptic properties. The administration of the selected biscuit to growing rats was able to significantly improve tail length and tended to increase body weight, but not significantly, in the experimental rats. Thus, Bilih fish biscuit may be considered a local-based potential alternative food that is rich in nutrients, especially omega-3 fatty acids, to help improve growth in human subjects in the future.

\section{ACKNOWLEDGEMENT}

The authors would like to thank the Directorate of Research and Community Service of the Directorate General of Research and Development Strengthening of the Ministry of Research, Technology, and Higher Education through the Competitive Grant of Doctoral Research Dissertation, which has funded this research under Contract Number: 050/SP2H/LT/ DRPM/2018.

We also convey our gratitude to the Faculty of Public Health of Andalas University Competitive Grant for Doctoral Research Dissertation, Contract Number 002/BPPT/ SPK/PNP/FKM/Unand-2018, as well as the Departement of Community Nutrition and Faculty of Veterinary Medicine of IPB University for supporting the research. The authors have no conflict of interest.

\section{REFERENCES}

[AOAC] Association of Official Analytical Chemist. 2005. Official Method of Analysis of AOAC International 18th Edition. Maryland (Adanya ver .ini): AOAC International.

[AOAC] Association of Official Analytical Chemistry. 2001. AOAC official Method 996.06 Fat (Total, Saturated, and Unsaturated) in Food Hydrolytic
Extraction Gas Chromatographic Method First Action 1996 Revised 2001. USA.

[BAPPENAS] Badan Perencanaan Pembangunan Nasional. 2015. Rencana Aksi Nasional Pangan dan Gizi Tahun 2015-2019. Jakarta: BAPPENAS.

Bernardi JR. 2012. Fetal and neonatal levels of omega-3: Effects on neurodevelopment, nutrition, and growth. The Scientific World Journal 2012: 1-8. http://dx.doi. org/10.1100/2012/202473.

Diana FM. 2013. Omega 3 dan kecerdasan anak. Jurnal Kesehatan Masyarakat 7(2):82-88. https://doi.org/10.24893/jkma.v7i2.113 org/10.1100/2012/202473.

Firmansyah H, Roosita K, Kusharto CM, Handharyani E. 2017. Pemberian minyak ikan lele (Clarias gariepinus) terhadap bobot badan dan perubahan histopatologi hati, ginjal, dan otak tikus srague dawley yang diberi pakan hiperkolesterolemia. J Gizi Pangan 12(2):85-92. https://doi. org/10.25182/jgp.2017.12.2.85-92.

[FDA] Food and Drugs Administration. 2005. Guidance for Industry: Estimating the Maximum Safe Starting Dose in Intial Clinical Trial for Therapeuthics in Adult Health Volunteers. Rocklville: FDA

[Kemenkes] Kementerian Kesehatan RI. 2013. Peraturan Menteri Kesehatan RI nomor 75 tahun 2017 tentang Angka Kecukupan Gizi yang Dianjurkan bagi Bangsa Indonesia. Kemenkes RI, Jakarta.

Kartamihardja ES, Sarnita, A. 2010. Populasi Ikan Bilih di Danau Toba: Keberhasilan Introduksi Ikan, Implikasi Pengelolaaan dan Prospek Masa Depan. Jakarta: Pusat Penelitian Pengelolaan Perikanan dan Konservasi Sumberdaya Ikan.

Kartamihadja ES. 2015. Potential of CultureBased Fisheries in Indonesian Inland Waters. In: Sena SDS, Bret AI, Simon $\mathrm{W}$ (eds). Perspectives on culture-based fisheries developments in Asia. Bangkok: Network of Aquaculture Centres in AsiaPacific.

Khan MU, Hassan MF, Rauf A. 2017. Determination of trans fat in selected fast food products and hydrogenated fats of India using attenuated total reflection fourier transform infrared (ATR-FTIR) spectroscopy. J Oleo Sci 66(3):251-257. https://doi.org/10.5650/jos.ess 16168 . 
Diana et al.

Mattjik AA, Sumertajaya IM. 2013. Perancangan Percobaan dengan Aplikasi SAS dan Mintab. Bogor: IPB Press.

Setyaningsih D, Apriyantono A, Sari MP. 2010. Analisis Sensori untuk Industri Pangan dan Agro. Bogor: IPB Press.

Simarmata N, Tiangsa S, Faranita T, Winra P. 2012. Peranan asam lemak esensial terhadap perkembangan otak dan ketajaman penglihatan. Majalah Kedokteran Nusantara 45(3):177-181.

Singh M. 2005. Essential fatty acids, DHA and human brain. Indian J Pediatr 7(3):239242. https://doi.org/10.1007/BF02859265.

Stewart CP, Christian P, LeClerq SC, West KP, Khatry SK. 2009. Antenatal supplementation with folic acid + iron + zinc improves linear growth and reduces peripheral adiposity in school-age children in rural Nepal. Am J Clin Nutr 90(1):132-140. https://doi.org/10.3945/ ajen.2008.27368.

Sholichah Z. 2007. Mengenal Jenis Tikus. Balaba 5(2):18-19.

Syandri,H.2008.Ancamanterhadapplasmanutfah ikan Bilih (Mystacoleucus padangensis Blkr) dan upaya pelestariannya di Danau Singkarak. [Scientific Oration at the
Inauguration Ceremony of the Permanent Professor of the Faculty of Fisheries and Marine Sciences, Bung Hatta University]. Padang: Bung Hatta University Press.

Wargo SG, Jacobs J, Auestad N, O'Connor LO, Moore JJ, Lerner E. 2005. Body composition in preterm infants who are fed long-chain polyunsaturated fatty acids: A prospective, randomized, controlled trial. Pediatric Research 57(5):712-718.

Watkins BA, Li Y, Lippman HE, Feng S. 2003. Modulatory effect of omega-3 polyunsaturated fatty acids on osteoblast function and bone metabolism. Prostaglandins Leukotrienes and Essential Fatty Acids 68(1):387-398. https://doi. org/10.1016/S0952-3278(03)00063-2.

Widodo S. 2015. Perbaikan Status Gizi Anak Balita Dengan Intervensi Biskuit Berbasis Blondo, Ikan Gabus (Channa striata), dan Beras Merah (Oryza nivara). [Disertation]. Bogor: IPB.

Yuniritha E, Juffrie M, Ismail D, Pramono S. 2014. The analysis of nutrient, and acute toxicity test extracts of billih fish (Mystacoleucus-padangensis) as local food quality for zinc supplementation. Food Science and Quality Management 33:97-104. 